\title{
Penerapan Model Pembelajaran Atraktif Berbasis Multiple Intelligences Tentang Pemantulan Cahaya pada Cermin
}

\author{
Intan Kusumawati ${ }^{1)}$, Stepanus Sahala $S^{2)}$, Haratua T.M.S ${ }^{2)}$ \\ 1) STKIP Singkawang, Kota Singkawang, Indonesia \\ E-mail: intankusumawati10@gmail.com \\ ${ }^{2)}$ Universitas Tanjungpura, Kota Pontianak, Indonesia
}

\begin{abstract}
Abstrak. Penelitian ini bertujuan untuk mengetahui efektivitas penerapan model pembelajaran atraktif berbasis multiple intelligences dalam meremediasi miskonsepsi siswa tentang pemantulan cahaya pada cermin. Pada penelitian ini digunakan bentuk pre-eksperimental design dengan rancangan one group pretest-post test design. Alat pengumpulan data berupa tes pilihan ganda dengan reasoning. Hasil validitas sebesar 4,08 dan reliabilitas 0,537. Siswa dibagi menjadi lima kelompok kecerdasan, yaitu kelompok linguistic intelligence, mathematical-logical intelligence, visual-spatial intelligence, bodily-khinestetic intelligence, dan musical intelligence. Siswa membahas konsep fisika sesuai kelompok kecerdasannya dalam bentuk pembuatan pantun-puisi, teka-teki silang, menggambar kreatif, drama, dan mengarang lirik lagu. Efektivitas penerapan model pembelajaran multiple intelligences menggunakan persamaan effect size. Ditemukan bahwa skor effect size masing-masing kelompok berkategori tinggi sebesar 5,76; 3,76; 4,60; 1,70; dan 1,34. Penerapan model pembelajaran atraktif berbasis multiple intelligences efektif dalam meremediasi miskonsepsi siswa. Penelitian ini diharapkan dapat digunakan pada materi fisika dan sekolah lainnya.
\end{abstract}

Kata Kunci: Model Pembelajaran Atraktif; Multiple Intelligences; Pemantulan Cahaya

\section{PENDAHULUAN}

Miskonsepsi atau salah konsep merujuk pada suatu konsep yang tidak sesuai dengan pengertian ilmiah yang diterima para pakar bidang itu, yang dapat berupa konsepsi awal dan akhir, kesalahan, hubungan yang tidak benar antara konsep-konsep, gagasan intuitif atau pandangan yang naif [1]. Ditemukannya miskonsepsi siswa tentang pemantulan cahaya pada cermin oleh Nasution, mengindikasi bahwa diperlukan suatu langkah untuk perbaikannya [2]. Hal ini seperti yang dilansir Suparno, satu di antara langkahnya adalah dengan memilih dan menerapkan perlakuan yang sesuai untuk mengatasi miskonsepsi tersebut [1]. Penerapan dalam penelitian ini berbentuk remediasi miskonsepsi siswa.

Sutrisno menjelaskan bahwa remediasi adalah kegiatan perbaikan yang diarahkan untuk mengatasi kesalahan konsepsi siswa dengan cara mengubah, memperbaiki atau memperjelas kerangka berpikir siswa [3]. Solusi yang diberikan adalah dengan penerapan model pembelajaran atraktif berbasis multiple intelligences.

Adapun alasan pemilihan remediasi dengan model pembelajaran atraktif berbasis multiple intelligences karena model pembelajaran ini memunculkan suatu keterbukaan pemikiran; dapat memanfaatkan ide kreatif yang dimiliki siswa; mengembangkan sikap mandiri siswa dalam memecahkan permasalahan melalui proses pikir kreatif siswa; terjalinnya kebebasan berekspresi; kerjasama kelompok; serta adanya penghargaan (reward), sehingga dapat meningkatkan ketertarikan dan minat belajar fisika yang pada pelaksanaannya diharapkan dapat mengurangi kesalahan konsepsi dan kesulitan belajar siswa. Hal ini dipertegas oleh Sugiharti, ditemukan bahwa pendekatan dengan multiple intelligences bermanfaat dalam pembelajaran karena dapat digunakan untuk menyelesaikan permasalahan dan memperdalam konsep yang dimiliki siswa [4]. Siswa yang tidak memiliki kecerdasan logismatematis juga dapat mempelajari fisika berdasarkan ragam kecerdasan yang dimilikinya, 


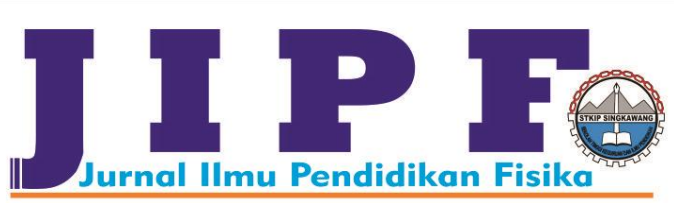

sehingga semua siswa dapat ikut 'menikmati' belajar fisika.

Multiple intelligences merupakan bahasa yang digunakan oleh Gardner untuk mendeskripsikan bahwa setiap manusia memiliki beragam kecerdasan/kecerdasan majemuk. Multiple intelligences memengaruhi proses kegiatan pembelajaran di sekolah, sebab ketika guru mengetahui kecenderungan kecerdasan seorang siswa dari multiple intelligences yang dimiliki siswa, maka guru akan dapat mengetahui gaya belajar siswa tersebut, sehingga memudahkan guru untuk menyampaikan informasi ke otak siswa [5].

Chatib menjelaskan pada dasarnya gaya mengajar adalah strategi transfer informasi yang diberikan oleh guru kepada siswanya [6]. Sedangkan gaya belajar adalah bagaimana sebuah informasi dapat diterima dengan baik oleh siswa.

Berdasarkan penelitian yang dilakukan oleh Gardner, ternyata gaya belajar siswa tercermin dari kecenderungan kecerdasan yang dimiliki oleh siswa tersebut [5]. Oleh karena itu, seharusnya setiap guru memiliki data tentang gaya belajar siswanya masing-masingdan setiap guru harus menyesuaikan gayanya dalam mengajar dengan gaya belajar siswanya, sehingga siswa merasa nyaman dan tidak berhadapan dengan risiko kegagalan dalam proses belajar.

Penerapan model pembelajaran multiple intelligences ditekankan pada belajar sambil bermain melalui pembuatan permainan drama, pantun puisi, menggambar kreatif, teka-teki silang, dan mengarang lagu dalam memahami konsep pemantulan cahaya pada cermin. Blum menyatakan bahwa metode permainan dapat membantu mengatasi kesulitan belajar siswa [7]. Selain itu, dapat pula meningkatkan hasil belajar siswa dengan memberikan effect size yang tinggi, yakni peningkatan hasil belajar siswa sebesar 17\% [8].

Penelitian ini bertujuan untuk mengetahui efektivitas penerapan model pembelajaran atraktif berbasis multiple intelligences dalam meremediasi miskonsepsi siswa tentang pemantulan cahaya pada cermin. Penelitian ini berlandaskan hasil temuan dari penelitian sebelumnya mengenai miskonsepsi siswa terhadap materi pemantulan cahaya pada cermin di kelas VIII, dengan pemilihan tempat penelitian yang sama. Penelitian ini diharapkan
Jurnal Ilmu Pendidikan Fisika

Volum 1 Nomor 1 Maret 2016. Halaman 5-8 p-ISSN: 2477-5959 e-ISSN: 2477-8451

dapat mengatasi miskonsepsi siswa dalam memahami konsep pemantulan cahaya pada cermin.

\section{METODE}

Metode dalam penelitian ini adalah metode eksperimen, dengan bentuk pre-eksperimental design dengan rancangan one group pretest-post test design. Siswa diberi soal pre-test, selanjutnya diberi treatment/perlakuan berupa penerapan model pembelajaran atraktif berbasis multiple intelligences, langkah terakhir adalah pemberian lembar soal post-test pada siswa.

Model pembelajaran atraktif dalam penelitian ini memiliki sintaks merujuk pada sintaks model pembelajaran treffinger. Model pembelajaran treffinger merupakan pembelajaran kreatif dengan basis kematangan dan pengetahuan yang siap. Adapun sintaks dari model pembelajaran treffinger, yaitu (1) keterbukaan - urun ide - penguatan, (2) penggunaan ide kreatif - konflik internal - skill (keterampilan), (3) proses rasa pikir kreatif dalam pemecahan masalah secara mandiri melalui pemanasan - minat - kurositi (kecurigaan/rasa penasaran) - tanya, (4) kelompok - kerjasama, (5) kebebasan - terbuka, reward (penghargaan) [9].

TABEL 1

TANTANGAN KELOMPOK KECERDASAN DALAM MODEL PEMBELAJARAN ATRAKTIF BERBASIS MULTIPLE INTELLIGENCES

\begin{tabular}{|c|c|c|}
\hline No. & Kelompok & Tantangan \\
\hline 1 & $\begin{array}{l}\text { Linguistic } \\
\text { Intelligence }\end{array}$ & $\begin{array}{l}\text { membuat sebuah puisi dan beberapa } \\
\text { pantunberdasarkan konsep fisika tentang } \\
\text { pemantulan cahaya pada cermin. }\end{array}$ \\
\hline 2 & $\begin{array}{l}\text { Logical- } \\
\text { Mathematic } \\
\text { al } \\
\text { Intelligence }\end{array}$ & $\begin{array}{l}\text { membuat sebuahTTS dengan pertanyaan- } \\
\text { pertanyaan yang berkaitan dengan konsep } \\
\text { fisika tentang pemantulan cahaya pada } \\
\text { cermin. }\end{array}$ \\
\hline 3 & $\begin{array}{l}\text { Visual- } \\
\text { Spatial } \\
\text { Intelligence }\end{array}$ & $\begin{array}{l}\text { membuat gambar-gambar } \\
\text { berdasarkan pada konsep pemantulan } \\
\text { cahaya pada cermin. }\end{array}$ \\
\hline 4 & $\begin{array}{l}\text { Bodily- } \\
\text { Kinesthetic } \\
\text { Intelligence }\end{array}$ & $\begin{array}{l}\text { membuat beberapa drama singkat tanpa } \\
\text { kata (pantomim) untuk menjelaskan suatu } \\
\text { konsep fisika melalui gerakan berdasarkan } \\
\text { konsep fisika tentang pemantulan cahaya } \\
\text { pada cermin. }\end{array}$ \\
\hline 5 & $\begin{array}{l}\text { Musical } \\
\text { Intelligence }\end{array}$ & $\begin{array}{l}\text { membuat sebuah lagu dengan mengganti } \\
\text { syair lagu kesukaan mereka dengan konsep- } \\
\text { konsep fisika tentang pemantulan cahaya } \\
\text { pada cermin. }\end{array}$ \\
\hline
\end{tabular}

Pada penelitian ini, mahasiswa dibagi menjadi lima kelompok kecerdasan, yaitu linguistic intelligence, mathematical-logical intelligence, visual-spatial intelligence, bodily-khinestetic 


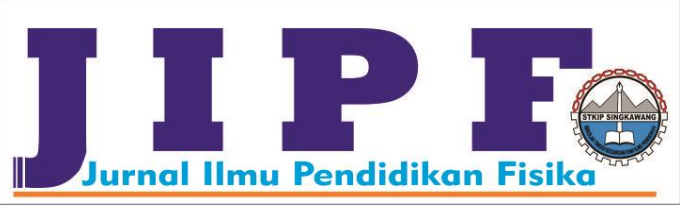

intelligence, dan musical intelligence berdasarkan lembar kuesioner kecerdasan. Adapun tantangan kelompok kecerdasan dalam model pembelajaran ini, ditampilkan pada Tabel 1 .

Penentuan tingkat efektivitas penerapan model pembelajaran atraktif berbasis multiple intelligencesini ditinjau dari kelompok kecerdasan siswa, digunakan rumus effect size $\left(\mathrm{E}_{\mathrm{s}}\right)$ dengan menghitung selisih mean post-test dan pretestdibagi standar deviasi (SD).

$$
E_{s}=\frac{M_{2}-M_{1}}{S D}
$$

Kriteria besarnya effect size diklarifikasikan pada kriteria tinggi $\left(E_{\mathrm{s}}>0,8\right)$, sedang $\left(0,2<\mathrm{E}_{\mathrm{s}} \leq 0,8\right)$, dan rendah $\left(\mathrm{E}_{\mathrm{s}} \leq 0,2\right){ }^{[3]}$. Jika tingkat effect size yang ditemukan berkategori tinggi atau sedang, maka penerapan model pembelajaran atraktif berbasis multiple intelligences efektif meremediasi miskonsepsi siswa tentang pemantulan cahaya pada cermin, selain dari itu penerapan model pembelajaran multiple intelligences dikatakan tidak efektif untuk meremediasi miskonsepsi siswa tentang pemantulan cahaya pada cermin .

\section{HASIL DAN PEMBAHASAN}

Untuk mengetahui efektivitas penerapan model pembelajaran atraktif berbasis multiple intelligences untuk meremediasi miskonsepsi siswa kelas VIII tentang pemantulan cahaya pada cermin jika ditinjau dari kelompok kecerdasan siswa, maka digunakan perhitungan effect size. Pada penelitian ini, effect size kelompok Linguistic Intelligence (LI) sebesar 5,76 dengan kategori tinggi, effect size kelompok Logical-Mathematical Intelligence (LMI) sebesar 3,76 dengan kategori tinggi, effect size kelompok Visual-Spatial Intelligence (VSI) sebesar 4,60 dengan kategori tinggi, effect size kelompok Bodily-Khinestetic Intelligence (BKI) sebesar 1,70 dengan kategori tinggi, dan effect size kelompok Musical Intelligence (MI) sebesar 1,34 dengan kategori tinggi.

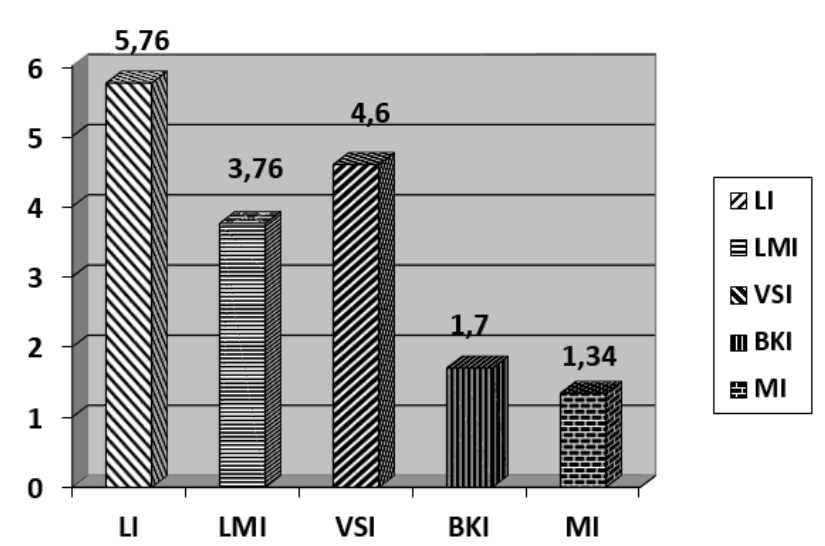

Gambar. 1 Grafik Skor Effect Size Penerapan Model Pembelajaran Atraktif Berbasis Multiple Intelligences

Skor effect size pada kelompok linguistic intelligence lebih besar dibandingkan dengan kelompok kecerdasan lain, sebab penerapan model pembelajaran ceramah cenderung diterapkan selama siswa menempuh pendidikan formal, yaitu sejak dibangku sekolah dasar. Hal ini menyebabkan siswa menjadi terbiasa dengan pola mengajar yang lebih memprioritaskan penggunaan bahasa, baik berupa bahasa lisan maupun tulisan. Hal serupa terjadi pada kelompok musical intelligence, kelompok ini menjadi kelompok yang memiliki skor effect size terendah, yang cenderung disebabkan siswa belum terbiasa dalam memanfaatkan potensi musical intelligence-nya. Hasil skor effect sizememuat di tiap kelompok intelligence. Hal ini menunjukkan bahwa model pembelajaran multiple intelligences ini dapat diterapkan dalam kegiatan pembelajaran. Skor effect size untuk seluruh kelompok menunjukkan kategori tinggi. Tingginya skor ini menunjukkan bahwa model pembelajaran atraktif berbasis multiple intelligencesefektif dalam meremediasi miskonsepsi siswa tentang pematulan cahaya pada cermin di kelas VIII.

\section{KESIMPULAN}

Kesimpulan dari penelitian ini adalah Penerapan model pembelajaran atraktif berbasis multiple intelligences efektif meremediasi siswa pada materi pemantulan cahaya pada cermin di kelas VIII dengan kategori tinggi sesuai perhitungan effect size ditinjau dari kelompok kecerdasan siswa. Adapun saran dari penelitian ini yakni Sebaiknya model pembelajaran ini diterapkan pula pada materi fisika dan sekolah yang lain agar dapat memotivasi siswa dalam kegiatan pembelajaran. 


\section{DAFTAR PUSTAKA}

[1] Suparno, Paul, "Miskonsepsi dan Perubahan Konsep dalam Pendidikan Fisika”, Jakarta: Grasindo, 2005.

[2] Nasution, Nurul Huda, "Miskonsepsi Siswa Kelas VIII SMP Negeri 6 Pontianak Tentang Pemantulan Cahaya Pada Cermin", Pontianak: FKIP UNTAN (Skripsi), 2008.

[3] Sutrisno, Leo, “ Program Diagnostik Remediasi dalam IPA: Meta Analisis Laporan Penelitian", Pontianak: FKIP UNTAN, 1991

[4] Sugiharti, piping. (2005). "Penerapan Teori Multiple Intelligences Dalam Pembelajaran Fisika". [online]. Tersedia (http://www.bpkpenabur.or.id/files/29_42pipingsugihartiPenerapan\%2 0Teri\%20Multiple\%20dalam\%20Pembelajaran\%20Fisika.pdf,(online). Diakses 5 februari 2010.

[5] Gardner, Howard, "Multiple Intelligences: The Theory in Practice", New York, 2003.

[6] Chatib, Munif, "Sekolahnya Manusia: Sekolah Berbasis Multiple Intelligence di Indonesia", Bandung: Kaifa, 2009

[7] Blum, "The Remedial Effect of a Biological Learning Game", Journal of Katu, N.1995, Workshop On Misconseption In Basic Phyclas Teaching Part II, Makalah Medan Laboratorium Ilmu-Ilmu Dasar USU, 1979.

[8] Basuki Hardigaluh \& Tomo, "Efektivitas Penyediaan Bacaan Berbentuk Refutation Text untuk Meremediasi Kesalahan Konsep Suhu dan Kalor pasa siswa SLTP di Kodya Pontianak", Pontianak: Jurusan PMIPA FKIP UNTAN, 2002.

[9] Herdian. (2009). "Model Pembelajaran Treffinger". [Online]. Tersedia : (http://www.Vilila.com.model-belajar-dan-

pembelajaran.html\#ixzz1Ah73wERn). Diakses 29 Januari 2011. 